\title{
Potential of geotourism for regional development: the case of "Iron Gates" park in Serbia
}

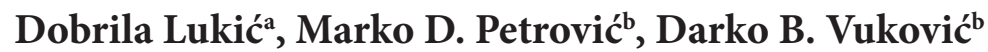 \\ ${ }^{a}$ Eighth Belgrade Grammar School, Belgrade, Serbia; e-mail: dobriladjerdap@gmail.com \\ ${ }^{b}$ Geographical Institute "Jovan Cvijić", Belgrade, Serbia
}

\begin{abstract}
This paper focuses on the case of "Iron Gates" National Park located along the Danube between Serbia and Romania and discusses the opportunities and prospects for developing geotourism. Apart from being an area of natural beauty, this park comprises a wide range of spectacular geological sites, historical and cultural monuments. The authors also examine the concept of geotourism and show its connection to other types of tourism such as nature tourism and adventure tourism. Using statistical methods and methods of comparative analysis, they analyse the data on tourism development in Đerdap (Serbia) and Mehedinţi County (Romania) in 2015. Such indicators as the number of tourists and overnight stays, the number of accommodation facilities, the coefficient of functionality, and so on are considered. The conclusion is made that the national park "Iron Gates" holds significant potential for the development of sustainable tourism in the region if the park's geoheritage sites are consolidated into a single tourism route "Iron Gates Geoheritage", which would be highly likely to become a successful product in the tourism market. This product could be presented either directly, as a tourist destination, or indirectly, through event tourism, excursions, transit tourism and so on, and offered to both domestic and international tourists.
\end{abstract}

\author{
KEYWORDS \\ geotourism, sustainable regional \\ development, "Iron Gates" \\ National Park, sustainable tourism, \\ Serbia, Romania
}

\section{FOR CITATION}

Lukić, D., Petrović, M. D., Vuković, D. B. (2018) Potential of geotourism for regional development: the case of "Iron Gates" park in Serbia. R-economy, 4(4), 158-166. doi: $10.15826 /$ recon.2018.4.4.021

\section{Потенциал геотуризма в качестве драйвера регионального развития: случай сербского парка «Железные врата»}

\author{
Д. Лукич ${ }^{\mathrm{a}}$, М. Д. Петрович ${ }^{\mathrm{b}}$, Д. Б. Вукович ${ }^{\mathrm{b}}$ \\ ${ }^{a}$ Восьмая белградская школа грамматики, Белград, Сербия; e-mail: dobriladjerdap@gmail.com \\ ${ }^{b}$ Географический институт «Йован Цвиич» Сербской академии наук, Белград, Сербия
}

\begin{abstract}
АННОТАЦИЯ
Эта статья посвящена национальному парку «Железные врата», расположенному вдоль Дуная между Сербией и Румынией, и в ней рассмотрены возможности и перспективы развития геотуризма. Помимо того, что район парка отличается природной красотой, он включает в себя широкий спектр впечатляющих геологических, исторических и культурных памятников. Авторы рассматривают понятие геотуризма и показывают его связь с другими видами туризма, такими как природный туризм и приключенческий туризм. Используя статистические методы и методы сравнительного анализа, они анализируют данные о развитии туризма в Чердапе (Сербия) и округе Мехединцы (Румыния) в 2015 г. Рассмотрены такие показатели, как количество туристов, ночевок, количество объектов размещения, коэффициент функциональности. Сделан вывод о том, что национальный парк «Железные врата» обладает значительным потенциалом для развития туризма в регионе, который будет реализован, если объекты геонаследия парка будут объединены в единый туристический маршрут «Географическое наследие Железных врат». Данный продукт с большой вероятностью станет успешным на туристическом рынке. Этот продукт может быть представлен либо напрямую, как туристическое направление, либо косвенно, посредством событийного туризма, экскурсий, транзитного туризма и т. д., и он может предлагаться как внутренним, так и международным туристам. (๖) Dobrila Lukić, Marko D. Petrović, Darko B. Vuković, 2018
\end{abstract}

\section{КЛЮЧЕВЫЕ СЛОВА}

геотуризм, устойчивое региональное развитие, Национальный парк «Железные врата», устойчивый туризм, Сербия, Румыния

\section{ДЛЯ ЦИТИРОВАНИЯ}

Lukić, D., Petrović, M. D., Vuković, D. B. (2018) Potential of geotourism for regional development: the case of "Iron Gates" park in Serbia. R-economy, 4(4), 158-166. doi: 10.15826/recon.2018.4.4.021 


\section{Introduction}

Before the 1980s, mass industrial tourism was a prevalent concept and the development of tourism was seen in terms of such economic indicators as profit and employment rates or gross national product. However, this approach had a negative effect on the environment and society. Such adverse impacts, in turn, were detrimental to the quality of tourism product resulting in a fall in the demand for destinations in which tourism caused environmental damage, was destructive to host communities and their cultures. Consequently, the idea of new, alternative tourism emerged, which boosted interest in sustainable products and sustainable development in all types of tourism [1].

Geotourism is tourism which aims to sustain or enhance natural environment and its geodiversity. It is a highly specialized type of tourism focused on geostructures (landscapes, reliefs, profiles, fossils and so on) and as such it is related to nature tourism and ecotourism [2-4]. Geotourists are usually interested in such activities as looking for fossils and interesting relief forms, going on tours and following theme trails. While visiting tour sites, tourists are informed by expert guides about the processes which result in the formation of geostructures. As a result, tourists will know more about the environment and the character of individual structures and processes. Thus, the concept of geotourism is to some extent similar to ecotourism and it can be considered desirable only if it encourages tourists and locals to treat the environment with respect. Geotourism can be based on both cultural and historical monuments if structures which are visited were built from local rocks. Geotours may also present the mining industry of the region so that tourists can see how geology influenced peoples' lives as well as negative effects that human activities had on the environment [5-7]. Geotours are usually rounded off with services offered at geoparks, at which geological heritage is protected and promoted through sustainable use of resources $[8 ; 9]$.

At the same time, the value of geodiversity can be attractive for those tourists who are interested in adventure activities such as mountaineering, amateur caving or trekking. Moreover, there are some elements of geodiversity that are essential for recreation, for instance, skiing, rafting, hiking or climbing. Thus, the relation between ecotourism and nature tourism can be compared to the one between geotourism and adventure tourism.
There are also activities that are more focused on enhancing tourists' understanding of the environment and improving the environment (ecotourism and geotourism), whereas in other cases tourists seek enjoyment, recreation and adventure (nature tourism and adventure tourism based on geodiversity).

To ensure sustainability in tourism, an integrated approach to planning and management is required. Any planning should be long-term and proactive, and plans should be integral to or in harmony with other ways of using the area. Finally, all plans must correspond to the needs of the host community. As for management, it should be comprehensive and in line with the industry sectors and activities relevant to the area; projected outcomes should be clearly stated and responsibilities, delegated. This understanding of planning and management is aimed at protecting the environment and ensuring sustainable use of natural resources. With a few adjustments and amendments, it can be applied to develop geotourist destinations [8-11].

\section{Geographical Location and Characteristics of "Iron Gates" Park}

The name "Iron Gates", or "Đerdap" in Serbian, denotes not only a gorge formed by the Danube making its way through the Southern Carpathians and connecting the Pannonian and Lower Danube Basins. It is also the name of the national park established in 1974. The park is located in the north-east of Serbia, in South-East Europe. Stretching along Serbia's border with Romania, the park lies in the territory of three municipalities: Golubac, Majdanpek and Kladovo. The "Iron Gates" park comprises four gorges separated by three valleys. The gorges alternate with the valleys in the following order from the west to the east: the Golubac Gorge, the Valley of Liubcova, the Lady's Eddy Gorge ("Gospodin vir"), the Valley of Donji Milanovac, the Kazani Gorge, the Oršava Valley and the Sipska Gorge. Main orographic features include the Golubac Mountains, Šomrda, Liškovac, Veliki Greben and Miroč. The valleys are formed by the Danube tributaries that run through the mountains and also feature a number of barren karst plateaus. A water reservoir belonging to the "Đerdap I Hydropower and Navigation System" was formed when a dam was constructed to hold back the Danube and raise its level. Since then, the reservoir has had a considerable impact on 
the environment, for instance, the weather conditions. The mean annual temperature (the village of Tekija $-11.4{ }^{\circ} \mathrm{C}$ ) and precipitation values (the village of Tekija $-801.9 \mathrm{~mm}$ ) in this area have been somewhat higher than the respective values in Serbia. In turn, the improvement of weather conditions has had a positive effect on the region's flora [12].

As for the demographic trends in the area, the entire territory has experienced depopulation since mortality and emigration rates exceed natality and immigration rates. Three major towns of the region are Golubac, Donji Milanovac and Kladovo. The main branches of industry include hydropower engineering ("Đerdap I" and "Đerdap II" Hydroelectric Power Plants), transportation (the Danube Pan-European Corridor VII), tourism, agriculture, fishing and fisheries, forestry, stone extraction in the village of Brnjica and copper mining in Majdanpek [13-16].

\section{Methodology}

This paper uses statistical methods to determine the number of visitors and overnight stays in Đerdap in Serbia and Mehedinţi County in Romania in 2015 as well as the number of accommodation facilities, the length of stay of tourists, coefficient of functionality, capacity utilization and intensity of functionality in Đerdap and the cross-border region of Mehedinţi. These data are then used in comparative analysis of tourism development in these regions.

The analysis focuses on four indicators: the length of stay of tourists, functionality coefficient, capacity utilization and intensity of functionality. The length of stay is calculated as the ratio of the number of nights to the number of tourists. The coefficient of functionality is the ratio of the number of beds to the number of guests; capacity utilization, the ratio of the number of nights to the number of beds during the year; and the intensity of functionality shows the amount of tourist traffic in the given location within a certain period.

\section{Geotourism in "Iron Gates" Park}

In addition to geodiversity and biodiversity (shown in Table 1 and 2 respectively) and cultural and historical heritage (Table 3), the "Iron Gates" park can attract visitors by its natural history exhibition displayed in the Visitor Centre, museums, hiking trails (see Table 4), cycling routes, leisure centres and a variety of popular events.
Out of the 651 geoheritage sites identified in Serbia, 26 are located in the "Iron Gates" area, which means that the park has vast potential for consolidating these sites into a single route that could be popular on the tourism market. Geoheritage sites could complement the tourism offer that is already available in this Serbian region [11].

Fourteen sites located in "Iron Gates" have been protected by the state as nature reserves and special nature reserves. In addition, seventeen cultural and historical monuments found in the territory have been placed under protection of "Iron Gates" National Park or have the status of historical or cultural monuments. Both natural and cultural heritage of "Iron Gates" has a considerable scientific, educational and tourism value [16; 18].

The most prominent peak in Gospođin Vir gorge is called Sokolovac and is located at the altitude of 625 meters, sprawling between two rivers Kozička and Pesača.

The entire Gospodin Vir gorge, from Bosman to Greben, can be observed from this lookout point. Greben, 199 meters above sea level, is located at the end of the hill Boljetinsko Brdo and has most peculiar geological formations.

A wonderful view of Donjomilanovačka ravine, from Greben to the far side of Golubinje, can be admired from Kovilovo, known also as Golo Brdo (a hill), which is located at the altitude of 358 meters. Ploče $(375 \mathrm{~m})$, Veliki Štrbac $(768 \mathrm{~m})$ and Mali Štrbac $(626 \mathrm{~m})$ are the highest peaks of Miroč Mountain as well as the most attractive lookout points in "Iron Gates" with breath-taking views over the Kazani gorges. They belong to the first level of protection because many animal and plant species can be found in their forest ecosystems. There are eight hiking trails in "Iron Gates" and some of them lead to the above-mentioned lookout points.

\section{Accommodation Facilities and Tourist Flows in "Iron Gates" Park}

In 2015, there were two establishments that belonged to the category of basic accommodation facilities in Golubac municipality, namely a twostar hotel and a B\&B. In total, these two establishments had 59 available rooms with 122 permanent and 50 extra beds (177 in total). As regards the category of complementary accommodation facilities, there were 21 one-star private rooms with 50 permanent beds and one extra bed. In total, there were 80 available rooms with 223 permanent and 51 extra beds (274 in total) [19]. 
Geoheritage sites in "Iron Gates"

Table 1

\begin{tabular}{|c|c|}
\hline \multicolumn{2}{|c|}{ GEOHISTORICAL AND STRATIGRAPHIC HERITAGE SITES } \\
\hline \multicolumn{2}{|c|}{ Palaeozoic sites } \\
\hline Profile of Lower Carboniferous olistromes & $\begin{array}{l}\text { Avramac creek valley, between Mountain Šomrda and River } \\
\text { Kosobrdska, outside Donji Milanovac }\end{array}$ \\
\hline Profile of Westphalian river sediments & River Boljetinska valley, outside Boljetina \\
\hline \multicolumn{2}{|c|}{ Jurassic sites } \\
\hline $\begin{array}{l}\text { Typical evolution profile in Southern Carpathians, between } \\
\text { the Permian and Jurassic periods }\end{array}$ & Pesača, by the roadside, "Iron Gates" National Park \\
\hline $\begin{array}{l}\text { Profile of liassic sediments with remnants of continental } \\
\text { macroflora }\end{array}$ & Dobra, on the Danube, "Iron Gates" National Park \\
\hline $\begin{array}{l}\text { Profile of Klaus facies or Klaus strata with predominantly } \\
\text { ammonite fauna }\end{array}$ & $\begin{array}{l}\text { Greben (Reef) on the Danube and River Boljetinska canyon, } \\
\text { Iron Gates National Park }\end{array}$ \\
\hline Profile of Klaus strata with predominantly ammonite fauna & Ribnica, outside Donji Milanovac \\
\hline $\begin{array}{l}\text { Stratotype profile, pelagic evolution in the Southern Car- } \\
\text { pathians }\end{array}$ & Veliki greben (Great Reef), outside Donji Milanovac \\
\hline Profile of Boljetina limestone formation (Jurassic period) & $\begin{array}{l}\text { the place where the River Boljetinska flows into the Danube, } \\
\text { outside Donji Milanovac }\end{array}$ \\
\hline
\end{tabular}

Profile of pelagic evolution in the Jurassic period bordering Lepensko Brdo (a hill), in the vicinity of the tunnel, Iron Gates on the Lower Cretaceous period National Park

Profile of shallow-water strata of Alb.-Cenom

Cretaceous sites

Profile of deep-water formations of Lower Cretaceous peri- Veliki Greben (Great Reef) hinterland, Donji Milanovac od (limestone and marly)

Džervin strata, Upper Cretaceous period

Džervin Hill on the Danube, between Negotin and Kladovo

\begin{tabular}{|l|l|}
\hline & Neogene sites \\
\hline Abundant fauna from the Middle Badenian stage & Donji Milanovac \\
\hline
\end{tabular}

\begin{tabular}{|c|} 
Abundant fauna from the Middle Badenian stage Donji Milanovac \\
\hline PETROLOGICAL HERITAGE SITES \\
Sedimentary rocks
\end{tabular}

Jurassic limestone

Dobra-Boljetin

Cretaceous limestone

Dobra-Boljetin

Igneous and metamorphic rocks

\begin{tabular}{|c|c|}
\hline Hercynian granite & River Porečka valley, from Miloševa Kula in the direction of Bor \\
\hline Amygdaloid spilite & Dobra-Donji Milanovac \\
\hline Carboniferous-Permian tuffs & Dobra-Donji Milanovac \\
\hline \multicolumn{2}{|c|}{ GEOMORPHOLOGICAL HERITAGE SITES } \\
\hline \multicolumn{2}{|c|}{ Fluvial relief } \\
\hline "Iron Gates" Gorge & "Iron Gates" National Park \\
\hline Boljetinska River canyon & "Iron Gates" National Park \\
\hline \multicolumn{2}{|c|}{ NEOTECTONIC STRUCTURES } \\
\hline \multicolumn{2}{|c|}{ Epeirogenic movement } \\
\hline Valleys of right-bank Danube tributaries & Ključ, near Kladovo \\
\hline \multicolumn{2}{|c|}{ SPELEOLOGICAL STRUCTURES } \\
\hline \multicolumn{2}{|c|}{ Caves } \\
\hline Gradašnica cave & Mosna \\
\hline \multicolumn{2}{|c|}{ Abysses } \\
\hline Buranov ponor & Golubinje \\
\hline Nemački ponor & Miroč \\
\hline Suvi ponor & Miroč \\
\hline Ibrin ponor & Miroč \\
\hline
\end{tabular}

Source: Inventory of Geoheritage Sites, 2004. 


\section{Nature reserves in "Iron Gates"}

\begin{tabular}{|l|l|}
\hline \multicolumn{1}{|c|}{ Reserve name } & \multicolumn{1}{c|}{ Reserve description } \\
\hline Golubac & $\begin{array}{l}\text { Mixed forest consisting of Oriental hornbeam and common lilac, ailanthus \& common li- } \\
\text { lac, beech \& Oriental hornbeam, Hungarian oak, Turkey oak, Oriental hornbeam and beech } \\
\text { with walnut }\end{array}$ \\
\hline Bojana & $\begin{array}{l}\text { Pure stands of walnut (Juglans regia) surrounded by mixed stands of beech and walnut } \\
\text { (Fagetum submontanum juglandetosum); individual trees of Turkish hazel, Montpelier ma- } \\
\text { ple, flowering ash \& common hornbeam }\end{array}$ \\
\hline Brnjica River Gorge & $\begin{array}{l}\text { Abundance of sessile oak and Turkish oak (Quercetum petraeae-cerris) } \\
\text { nut on limestones }\end{array}$ \\
\hline Tatarski Vis & Northernmost habitat of holly (Ilex aqufolium) \\
\hline Šomrda & Pure beech forest \\
\hline Tilva Toma & $\begin{array}{l}\text { Pure mixed forest of walnut and beech (Juglando-Fagetum moesiacae) on the limestone } \\
\text { substratum }\end{array}$ \\
\hline Ciganski potok Stream & Riparian area with Turkish hazel and common lilac \\
\hline Bosman-Sokolovac & Natural arboretum, 40 different plant species \\
\hline Čoka Njalta-Pesača & $\begin{array}{l}\text { Complex relict communities; relict forest of hackberry and walnut (Celto-Juglandetum) in } \\
\text { Serbia; individual stand of hackberry, walnut, downy oak, Montpellier maple and lilac }\end{array}$ \\
\hline Lepenski Vir & Willow belt \\
\hline Boljetin River-Greben & Forest of sessile oak and hornbeam \\
\hline Kovilovo & Mixed forest of beech and oak \\
\hline Gradašnica & $\begin{array}{l}\text { Abundance of Turkish hazel; endemic species (yew, Montpellier maple, hackberry, smoke- } \\
\text { tree \& common lilac) }\end{array}$ \\
\hline $\begin{array}{l}\text { Veliki Štrbac, Mali Štrbac } \\
\text { with Tabula Traiana }\end{array}$ & \\
\hline
\end{tabular}

Source: [17]

Table 3

Cultural and historical heritage sites in "Iron Gates"

\begin{tabular}{|l|l|}
\hline \multicolumn{1}{|c|}{ Object } & \multicolumn{1}{c|}{ Description of the object } \\
\hline Frontiers of the Roman Empire & Ancient fortification system along the right bank of the Danube \\
\hline Lepenski Vir & Early Mesolithic to Early Neolithic settlement (9500-5500 BC), Boljetin village \\
\hline Golubac Fortress & Medieval fortress at the entrance to the Djerdap Gorge \\
\hline Rudna Glava & Earliest centre of copper mining in the Balkans, near Majdanpek \\
\hline Kostol-Pontes/ Transdrobeta & Castrum Pontes, next to the Trajan's bridge, Kladovo \\
\hline Diana-Karataš Diana/Zanes-Station & Remains of a fortress and castle, downstream of the HPP Djerdap I, Kladovo \\
\hline Fetislam & Medieval fortress, Kladovo \\
\hline Miroč Castle & Remains of a Roman fortress \\
\hline Pena & Signal station between Mali Kazan and Veliki Kazan Gorge \\
\hline Stara Čaršija & Old bazaar crafts centre, Kladovo \\
\hline Saint Nicolas Church & Built in 1840 on the base of an old wooden church, Donji Milanovac \\
\hline Tumane Monastery & Monastery complex, near Golubac \\
\hline Golubinje traditional house & Reconstruction of an old traditional village, A part of Lepenski Vir complex \\
\hline Katarinine Livade & Bronze Age settlement \\
\hline Trajan' plaque/ Tabula Traiana & $\begin{array}{l}\text { Latin inscription dedicated to the Roman Emperor Nerva Trajan, carved in the } \\
\text { rock above the Danube River }\end{array}$ \\
\hline Miroč village & Traditional architecture, Miroč Mt. \\
\hline Manastirica Holy Trinity & Renovated monastery complex, Manastirica village (Novi Sip-Kladovo) \\
\hline
\end{tabular}
Source: [17] 
Hiking Trails in "Iron Gates"

\begin{tabular}{|c|c|c|c|c|c|c|c|}
\hline Trail & $\begin{array}{c}\text { Length } \\
(\mathbf{k m})\end{array}$ & \begin{tabular}{|c|} 
Average \\
Slope \\
$(\%)$
\end{tabular} & \begin{tabular}{|l|} 
Trail Dif- \\
ficulty \\
Rating
\end{tabular} & Trail Type & $\begin{array}{l}\text { Hiking } \\
\text { Time }\end{array}$ & Start & Finish \\
\hline $\begin{array}{l}\text { Bosman - } \\
\text { Sokolovac }\end{array}$ & 10 & 15 & Moderate & Hunting & $4 \mathrm{hrs}$ & $\begin{array}{l}\text { Belgrade - Kladovo high- } \\
\text { way }\end{array}$ & $\begin{array}{l}\text { Sokolovac, a moun- } \\
\text { tain peak and a look- } \\
\text { out point }(683 \mathrm{~m})\end{array}$ \\
\hline Gradašnica Cave & 2 & $15-20$ & Moderate & Mountaineering & $45 \mathrm{~min}$ & Miročki road & Gradašnica Cave \\
\hline $\begin{array}{l}\text { Buranov Ponor } \\
\text { (abyss) }\end{array}$ & 2.5 & $5-10$ & Easy & Tourist trail & $90 \mathrm{~min}$ & $\begin{array}{l}\text { Belgrade - Kladovo highway, } \\
\text { starting point at Dobra Voda }\end{array}$ & Buranov Ponor \\
\hline $\begin{array}{l}\text { Veliki Štrbac } \\
\text { and Mali Štrbac } \\
\text { (mt. peaks) }\end{array}$ & 9 & 20 & Moderate & Mountaineering & $3 \mathrm{hrs}$ & $\begin{array}{l}\text { Belgrade - Kladovo high- } \\
\text { way, starting point at Pecka } \\
\text { Bara }\end{array}$ & $\begin{array}{l}\text { Veliki Štrbac }(768 \mathrm{~m}) \\
\text { and Mali Štrbac } \\
(626 \mathrm{~m})\end{array}$ \\
\hline $\begin{array}{l}\text { Boljetinska River } \\
\text { canyon - Greben }\end{array}$ & 1.8 & 5 & Easy & $\begin{array}{l}\text { Recreational } \\
\text { trail }\end{array}$ & $30 \mathrm{~min}$ & Boljetinsko Hill & Greben \\
\hline $\begin{array}{l}\text { Balta Alu Sontu } \\
\text { lake - Glavica }\end{array}$ & 5 & 10 & Easy & $\begin{array}{l}\text { Recreational } \\
\text { trail }\end{array}$ & $2.5 \mathrm{hrs}$ & $\begin{array}{l}\text { Donji Milanovac, from } \\
\text { Paprenicki Creek }\end{array}$ & Balta Alu Sontu \\
\hline $\begin{array}{l}\text { Brnjička River } \\
\text { canyon }\end{array}$ & 21 & $10-20$ & Moderate & Tourist trail & $8 \mathrm{hrs}$ & $\begin{array}{l}\text { Forest path, at the exit from } \\
\text { village Brnjica }\end{array}$ & Rakovica village \\
\hline Kovilovo & 4 & $3-5$ & Easy & Tourist trail & $2.5 \mathrm{hrs}$ & $\begin{array}{l}\text { Regional road Donji Milano- } \\
\text { vac- Majdanpek via Oman }\end{array}$ & Kovilovo \\
\hline
\end{tabular}

Table 5

Accommodation Facilities in Golubac Municipality in 2015

\begin{tabular}{|l|r|r|r|r|r|}
\hline \multicolumn{1}{|c|}{ Golubac } & Establishments & Rooms & Total number of beds & Permanent beds & Extra beds \\
\hline Total & 2 & 80 & 223 & 172 & 51 \\
\hline Basic accommodation facilities & 2 & 59 & 172 & 122 & 50 \\
\hline Total number of hotels & 1 & 50 & 150 & 100 & 50 \\
\hline Two-star hotels & 1 & 50 & 150 & 100 & 50 \\
\hline Bed and Breakfast (Guest houses) & 1 & 9 & 22 & 22 & 0 \\
\hline Complementary accommodation facilities & 0 & 21 & 51 & 50 & 1 \\
\hline Total number of private rooms & $\ldots$ & 21 & 51 & 50 & 1 \\
\hline One-star private rooms & $\ldots$ & 21 & 51 & 50 & 1 \\
\hline
\end{tabular}

Source: Statistički godišnjak Republike Srbije (2015). Beograd: Republički zavod za statistiku.

Table 6

Accommodation Facilities in Majdanpek Municipality in 2015

\begin{tabular}{|l|r|r|r|r|r|}
\hline \multicolumn{1}{|c|}{ Majdanpek } & Establishments & Rooms & Total number of beds & Permanent beds & Extra beds \\
\hline Total & 2 & 370 & 762 & 738 & 24 \\
\hline Basic accommodation facilities & 2 & 300 & 580 & 580 & 0 \\
\hline Total number of hotels & 2 & 300 & 580 & 580 & 0 \\
\hline Three-star hotels & 2 & 300 & 580 & 580 & 0 \\
\hline Complementary accommodation facilities & 0 & 70 & 182 & 158 & 24 \\
\hline Total number of private rooms & $\ldots$ & 70 & 182 & 158 & 24 \\
\hline Two-star private rooms & $\ldots$ & 70 & 182 & 158 & 24 \\
\hline
\end{tabular}

Source: Statistički godišnjak Republike Srbije (2015). Beograd: Republički zavod za statistiku.

In the same year, there were registered two establishments that belonged to the category of accommodation facilities in Majdanpek municipality, namely two three-star hotels with 300 rooms and 580 permanent beds. In terms of complementary accommodation facilities, there were also 70 two-star private rooms with 158 permanent and 24 extra beds (182 in total). Overall, there were 370 available rooms with 738 permanent and 24 extra beds (762 in total) [19].

In Kladovo municipality in 2015 , three establishments were registered, two of which were hotels (a four-star hotel and a one-star hotel) and one children and youth resort. There were in total 430 rooms, 197 in the hotels and 233 in complementary accommodation facilities. There 
were 25 three-star private homes and apartments and 77 private rooms. The children and youth resort had 131 rooms with 360 permanent and 84 extra beds (444 in total). There were 1,052 permanent and 108 extra beds, in total 1,160. There were, therefore, seven establishments in "Iron Gates" with 880 rooms and 2,145 beds available (1962 permanent and 183 extra beds) [19].

According to official records, there were in total 46,773 tourist arrivals at "Iron Gates" in 2015, made by 37,620 domestic and 9,153 international tourists. There were in total $94,934 \mathrm{reg}$ istered overnight stays (75,459 domestic tourists and 19,475 international tourists). As can be seen from Table 5, in 2015, there was an upward trend in the number of both domestic and international visitors in 2015 in comparison with 2013 and 2014 [19].

\section{Comparison of Tourism in Đerdap and Mehedinți}

Table 9 shows the level of tourism development in Đerdap and Mehedinţi. Based on the available data, we can conclude that the length of stay of tourists in both destinations is about two days. Such a short period of stay can be explained by the decline in the purchasing power of the population, the rising prices of services,

Accommodation Facilities in Kladovo Municipality in 2015

Table 7

\begin{tabular}{|l|r|r|r|r|r|}
\hline \multicolumn{1}{|c|}{ Kladovo } & Establishments & Rooms & Total number of beds & Permanent beds & Extra beds \\
\hline Total & 3 & 430 & 1160 & 1052 & 108 \\
\hline Basic accommodation facilities & 2 & 197 & 471 & 459 & 12 \\
\hline Total number of hotels & 2 & 197 & 471 & 459 & 12 \\
\hline Four-star hotels & 1 & 53 & 71 & 71 & 0 \\
\hline Two-star hotels & 1 & 144 & 400 & 388 & 12 \\
\hline Complementary accommodation facilities & 1 & 233 & 689 & 593 & 96 \\
\hline Children and youth Resorts & 1 & 131 & 444 & 360 & 84 \\
\hline Total number of private rooms & $\ldots$ & 77 & 183 & 178 & 5 \\
\hline Three-star private rooms & $\ldots$ & 77 & 183 & 178 & 5 \\
\hline Total number of private apartments & $\ldots$ & 25 & 62 & 55 & 7 \\
\hline Three-star private apartments & $\ldots$ & 25 & 55 & 7 & \\
\hline
\end{tabular}

Source: Statistički godišnjak Republike Srbije (2015). Beograd: Republički zavod za statistiku.

Table 8

Tourist Flows in Iron Gates for the Period 2013-2015

\begin{tabular}{|c|l|r|r|r|r|r|r|}
\hline \multirow{2}{*}{ Year } & \multirow{2}{*}{ Municipality } & \multicolumn{3}{|c|}{ Arrivals } & \multicolumn{3}{|c|}{ Overnight stays } \\
\cline { 2 - 8 } & & \multicolumn{1}{|c|}{ Total } & Domestic & International & Total & Domestic & International \\
\hline \multirow{3}{*}{2015} & Kladovo & 22,347 & 18,791 & 3,556 & 49,326 & 40,810 & 8,516 \\
\cline { 2 - 8 } & Majdanpek & 21,507 & 16,876 & 4,631 & 41,751 & 31,910 & 9,841 \\
\cline { 2 - 8 } & Golubac & 2,919 & 1,953 & 966 & 3,857 & 2,739 & 1,118 \\
\hline \multirow{3}{*}{2014} & Kladovo & 16,050 & 13,293 & 2,757 & 39,102 & 30,757 & 8,345 \\
\cline { 2 - 8 } & Majdanpek & 22,523 & 17,795 & 4,728 & 43,596 & 34,874 & 8,722 \\
\cline { 2 - 8 } & Golubac & 2,766 & 2,152 & 614 & 4,000 & 3,258 & 742 \\
\hline \multirow{3}{*}{2013} & Kladovo & 23,746 & 20,610 & 3,136 & 63,577 & 55,715 & 7,862 \\
\cline { 2 - 8 } & Majdanpek & 25,562 & 20,979 & 4,583 & 51,924 & 42,838 & 9,086 \\
\cline { 2 - 8 } & Golubac & 4,962 & 4,426 & 536 & 8,878 & 8,120 & 758 \\
\hline
\end{tabular}

Source: Statistički godišnjak Republike Srbije (2015). Beograd: Republički zavod za statistiku.

Table 9

Tourism development of Đerdap and Mehedinţi

\begin{tabular}{|l|r|r|r|r|r|r|r|r|}
\hline $\begin{array}{c}\text { Tourist development } \\
\text { indicators }\end{array}$ & $\begin{array}{c}\text { Number of } \\
\text { inhabitants } \\
\text { (2011 Census) }\end{array}$ & $\begin{array}{c}\text { Number } \\
\text { of tourists }\end{array}$ & $\begin{array}{c}\text { Number } \\
\text { of nights }\end{array}$ & $\begin{array}{c}\text { Number } \\
\text { of beds }\end{array}$ & $\begin{array}{c}\text { Length of } \\
\text { stay (per } \\
\text { day) }\end{array}$ & $\begin{array}{c}\text { Functiona- } \\
\text { lity coeffi- } \\
\text { cient (\%) }\end{array}$ & $\begin{array}{c}\text { Capacity } \\
\text { utilization } \\
\text { (\%) }\end{array}$ & $\begin{array}{c}\text { Functiona- } \\
\text { lity intensi- } \\
\text { ty (\%) }\end{array}$ \\
\hline Derdap (Serbia) & 49,650 & 46,773 & 94,934 & 2,145 & 1.9 & 4.3 & 12.1 & 94.2 \\
\hline Mehedinţi (Romania) & 265,390 & 81,003 & 165,641 & 2,174 & 2.0 & 0.8 & 20.9 & 30.52 \\
\hline
\end{tabular}

Source: Statistički godišnjak Republike Srbije (2015). Beograd: Republički zavod za statistiku; National Institute of Statistics. Retrieved from: http://statistici.insse.ro/shop/ 
underdeveloped tourism infrastructure and lack of advertising. The coefficient of functionality in Đerdap (4.3\%) is much higher than in Mehedinţi $(0.8 \%)$ : both destinations have approximately the same number of beds, but the number of inhabitants in Mehedinţi is about five times higher than the number of inhabitants in Đerdap. However, this indicator also points to greater sustainability of tourism in the Romanian region, as the local population is not burdened by the construction of infrastructure. The low utilization of accommodation capacities - $12.1 \%$ - shows that economically, tourism in Đerdap still has a long way to go. The intensity of functionality in Đerdap is very high (94.2\%) and is almost three times higher than in Mehedinţi. According to our findings, the tourist traffic in Đerdap significantly exceeds the number of local residents, which means that there is demand for this destination which the host community might benefit from in the future through involvement in travel business, participating in cross-border projects and infrastructural development.

\section{Conclusion}

"Iron Gates" National Park has much potential for consolidating geoheritage sites into a single tourist route called "Iron Gates Geoheritage", which would in all probability enjoy success in the tourism market. Geoheritage sites could be incorporated into the current tourism offer that is already available in both regions. In this case, geo- heritage sites could be presented either directly, as tourist destinations, or indirectly through event tourism, excursions, transit and other types of tourism. Geoheritage sites usually appeal to tourists if they are related to tours of archaeological sites, hiking tours and cultural tours or, in other words, recreational and educational tours.

The potential of both regions for the development of geotourism stems from their border positions and the low pressure that such sustainable tourism puts on the environment. Both regions are characterized by geodiversity, biodiversity and abundant cultural heritage. Some financial investment is required, however, to restore and build the necessary tourism infrastructure and to make the tourism industry more efficient. Other problems to deal with are the decline in the local population, which can lead to personnel shortages, poor management of natural and cultural resources and economic instability, resulting in the declining purchasing power of tourists coming to this destination. The orientation of tourist agencies towards inbound rather than outbound tourism, as well as targeted and professional promotion of geo-tourism will surely improve the tourism development of Đerdap and Mehedinţi regions. In the future, it would be necessary to consider the positive and negative effects of an increase in the number of tourist arrivals as this trend may be detrimental to the park's eco-system, put excessive load on the carrying capacity of the park's sites and influence the quality of tourist services.

\section{References}

1. Jovičić, D. (2000). Turizam i životna sredina - koncepcija održivog razvoja. Beograd: Zadužbina Andrejević. (In Serbian).

2. Simić, S., Gavrilović, Lj, \& Đurović P. (2010). Geodiverzitet i geonasleđe - novi pristup tumačenju pojmova. Glasnik Srpskog geografskog društva, sveska, 90(2), 1-8. (In Serbian).

3. Vud, M. (2002). Ekoturizam, principi, postupci i politike za održivost. Beograd: Centar za odgovorni i održivi razvoj turizma. (In Serbian).

4. Belij, S. (2008). Geodiverzitet i geonasleđe u razvoju geomorfologije i zaštite prirode. Zaštita prirode, 58/1-2, 5-14. (In Serbian).

5. Hose, T. A. (2005). Geo-tourism - appreciating the deep time of landscapes. In M. Novelli (Ed.), Niche Tourism: contemporary issues, trends and cases (pp. 27-37). Oxford: Elsevier Science.

6. Hose, T. A. (2007) Geotourism in Almeria province, southeast Spain. Tourism, 55, 259-276.

7. Hose, T. A. (2008) Towards a history of Geotourism: definitions, antecedents and the future. In C. V. Burek, \& C. D. Prosser (Eds), The History of Geoconservation (pp. 37-60). London, UK: Geological Society of London.

8. Stojanović, V. (2006). Održivi razvoj turizma i životne sredine. Novi Sad: Univerzitet u Novom Sadu, Prirodno-matematički fakultet, Departman za geografiju, turizam i hotelijerstvo. (In Serbian).

9. Stojanović, V., Stamenković, I. (2008). Geoturizam u strukturi savremenih turističkih kretanja. Glasnik Srpskog geografskog društva, sveska, 88(4), 53-58. (In Serbian). 
10. Maksin, M., Pucar, M., Korać, M., \& Milijić, S. (2009). Menadžment prirodnih i kulturnih resursa u turizmu. Beograd: Univerzitet Singidunum, Fakultet za turistički i hotelijerski menadžment. (In Serbian).

11. Lukić, D. (2015). Geonasleđe srpskog Podunavlja u funkciji održivog razvoja turizma. Beograd: Geografski fakultet, doktorska disertacija. (In Serbian).

12. Lukić, D. (2005). Đerdapska klisura. Beograd: Srpsko geografsko društvo. (In Serbian).

13. Belij, S., \& Belij, M. (2009): Objekti geonasleđa srpskog Podunavlja i uslovi za razvoj geoturizma. Turističko poslovanjebroj, 4, 127-144. (In Serbian).

14. Belij, S. (2008). Stanje i zaštita geodiverziteta i objekata geonasleđa u Srbiji. Zaštita prirode, 60/1-2, 349-358. (In Serbian).

15. Jojić Glavonjić, T. (2010). Upravljanje i planska zaštita geonasleđa Srbije. Beograd: Geografski fakultet, magistarski rad. (In Serbian).

16. Rabrenović, D., Belij, S., Mojsić, I., Mladenović, M. (2014). Osnovne vrednosti područja Đerdapa, potencijalnog geoparka. In Zbornik radova XVI Kongresa geologa Srbije "Optimalno istraživanje i održivo korišćenje geoloških resursa”, Donji Milanovac, 22-25.05.2014 = Proceedings of the XVI Serbian Geological Congress "Optimal Research and Sustainable Usage of the Geological Resources". Donji Milanovac: Rudarsko-geološki fakultet. (In Serbian).

17. Djerdap National Park. Retrieved from www.geopark.npdjerdap.org

18. Lukić, D., \& Milovanović, D. (2014). A Contribution to the insight into Djerdap geoheritage. In Zbornik radova XVI Kongresa geologa Srbije "Optimalno istraživanje i održivo korišćenje geoloških resursa", Donji Milanovac, 22-25.05.2014 = Proceedings of the XVI Serbian Geological Congress "Optimal Research and Sustainable Usage of the Geological Resources". Donji Milanovac: Rudarsko-geološki fakultet. (In Serbian).

19. Lukić, D. (2017). Evaluation of Immovable Cultural Heritage of Great Importance in Iron Gates as Tourism Destination. (str. 2-17). In Second International Thematic Monograph - Thematic Proceedings: Modern Management Tools and Economy of Tourism Sector in Present Era. Belgrade: Association of Economists and Managers of the Balkans in cooperation with the Faculty of Tourism and Hospitality, Ohrid, Macedonia.

\section{Information about the authors}

Dobrila Lukić - PhD in Geography, Research Associate, Eighth Belgrade Grammar School (71 Grčića Milenka, Belgrade, Serbia); e-mail: dobriladjerdap@gmail.com.

Marko D. Petrović - PhD in Geosciences, Research Associate, Social Geography Department, Geographical Institute "Jovan Cvijić" of the Serbian Academy of Sciences and Arts (SASA) (9 Djure Jakšića, 11000 Belgrade, Serbia); e-mail: m.petrovic@gi.sanu.ac.rs.

Darko B. Vuković - PhD in Economy, Research Associate, Regional Geography Department, Geographical Institute "Jovan Cvijić" of the Serbian Academy of Sciences and Arts (SASA) (9 Djure Jakšića, 11000 Belgrade, Serbia); e-mail: d.vukovic@gi.sanu.ac.rs. 